\title{
Modelling and Analysis Methods of Integrated Information Systems of Transportation
}

\author{
SÁNDOR, Zsolt \\ Budapest University of Technology and Economics \\ (BME) \\ Faculty of Transportation Engineering and Vehicle \\ Engineering (KJK) \\ Department of Transport Technology and Economics \\ (KUKG) \\ H-1111, Stoczek street 2, Budapest, Hungary \\ zsolt.sandor@mail.bme.hu
}

\begin{abstract}
Information is one of the most important inputs for the activities in the transportation systems. The demands for information can be derived from the functions. Since modelling and analysis of particularly complex systems requires different techniques depending on the application purposes new methods have been introduced by us in order to facilitate the integration intentions. Our objective was to determine exact methods, which are applicable in the practice. The most important models have been adapted for the road transportation, because this mode has lags and here operates the most organizations.
\end{abstract}

Keywords- modelling, analysis, information system, integration

\section{INTRODUCTION}

The scope of intelligent transportation systems and services is continuously growing. New services emerge that increase the participants' needs for the integrated information management. In line with it, information technology (e.g. data collection and communication methods) is significantly evolving. Consequently, it is possible to collect large amounts of data about the users and the basic process of transportation.

Transportation organizations manage large amounts of information related to their duties. Most of the information is used by the data owner, and only a small proportion of the information is transmitted, while other organizations often have a need for data. In consequence, unexploited resources reside in the use of information, while the (quasi) real-time information represents significant value.

The development of information technology and scientific knowledge are interacting [1], [2], [4], [5]. The intelligent transportation systems apply several data collection and data processing technologies together [6], [7]. Some implementations apply raw and pre-processed data (originating from several sources) in an integrated way and give feedback too [8]. However, the majority of the implementations support the achievement of a specific objective (e.g. information provision), whereas the integrated accessibility between the functions is not realized. [9], [10] dealt with the physical establishment of integrated systems and the data flow within

\author{
CSISZÁR, Csaba (PhD) \\ Budapest University of Technology and Economics \\ (BME) \\ Faculty of Transportation Engineering and Vehicle \\ Engineering (KJK) \\ Department of Transport Technology and Economics
}

(KUKG)

H-1111, Stoczek street 2, Budapest, Hungary

csiszar.csaba@mail.bme.hu

the systems. These studies did not report on specific applications applied at transportation organizations; they discussed only the necessary background for the operation.

The objective of the modelling of the system of information in the transportation is to facilitate the telematics integration, which has already begun decades ago in the rail and air transportation. The objectives of the integrated information system are:

- the comprehensive and systematic managing of the transportation information,

- the production, sharing and transmission of value added information to the users of transportation,

- supporting the more efficient management of the traffic from the aspects of both operators and users by adaptation better to the actual needs and circumstances.

The telematics integration consists of several steps and it requires a long time. The results summarized here are the first step of this process. In this article the integration of information systems and services, within the scope of the horizontal integration has been discussed. Since the results of the comprehensive system and process-oriented scientific research on this area are rarely published, the devised modelling and analysis methods described here fill this niche.

This modeling and analysis method is a consequence of a continuous research work carried out at our department in the last decades. The techniques and the methods are continuously developed, improved and adapted [11], [12].

\section{MODEL OF THE TRANSPORTATION INFORMATION SYSTEM}

Two important terms have been defined (clarified):

Information system: is part of the company (subsystem), which provides procedures for creating, recording, processing and accessing the information. It is related either to the organization or to its specific part and it assists the organization to reach its goal. Information systems are the representations of the organizations, which provide information about the status 
2015 Models and Technologies for Intelligent Transportation Systems (MT-ITS)

3-5. June 2015. Budapest, Hungary

of the organization for the managing elements located at different levels in the hierarchy. For this purpose the machine system of the organization is used, which may consist of several subsystems.

System of information: set of systematically structured information considering certain aspects. Part of the information system.

During the modelling, the information system was analysed form structural and operational viewpoints. The components, processes and the related information were identified. Machine components and their processes were not analysed in detail because their implementations significantly depend on the actual level of technical development. Thus the conclusions are limited to the system of information in order to achieve results being valid for long period. The modelling of the system of information also assumes the (structural and operational) modelling of the transportation system, because the data maps the components and the processes [3].

Components of the transportation system have been grouped into:

- transportation base-system (technical and process system), and

- information system based on it.

Figure 1. illustrates the elaborated model of the transportation information system. During the modelling, the most important components were identified and their notation was introduced:

1. organization types (human and machine elements) $\left(O_{x}\right)$,

2. functions (procedures) $\left(F_{y}\right)$,

3. datasets (data elements), $\left(D_{z}^{i}\right.$, where index $i$ makes possible differentiation according to the temporal validity)

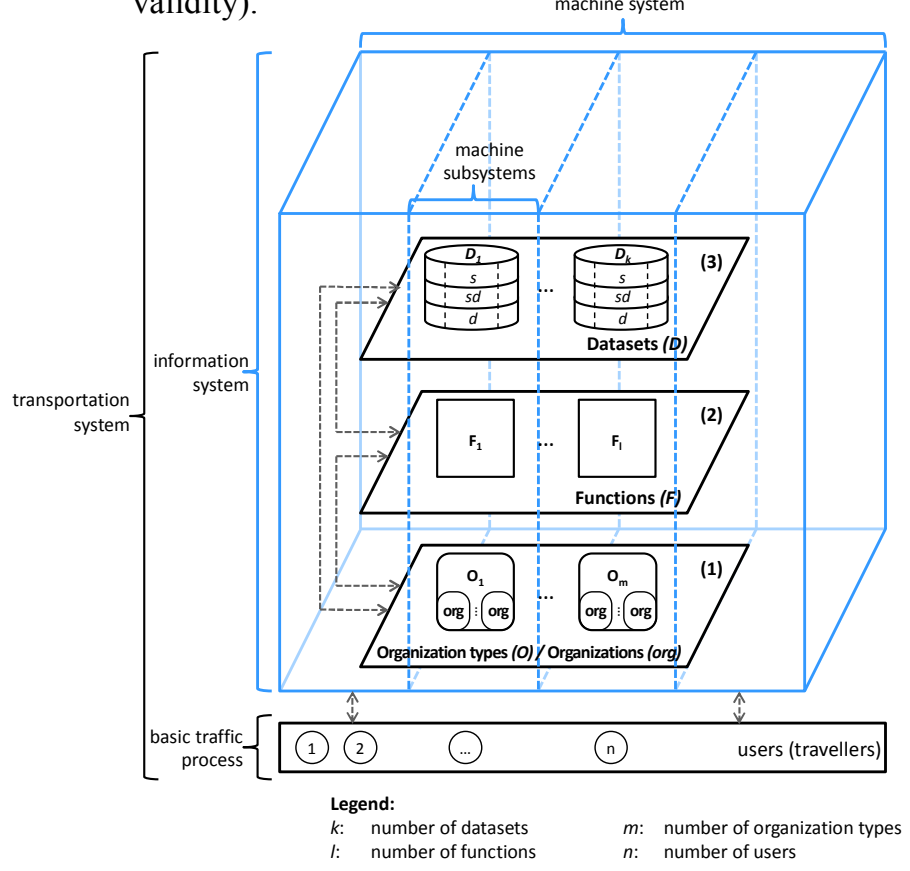

Fig. 1. Model of the transportation information system
As for the organization-function approach the main arranging principle is the function, consequently it has higher priority. The characteristics of organizations may often change, while the functions are mostly permanent.

The transportation system is formed by the participants in the transportation process and the information system that influences the operation. The information system makes the operation of the basic process of transportation possible. Machine subsystems interconnect the components of the information system and they provide the storage, transmission and procession of the information being necessary for the operation. In addition, they are interfaces between the travellers and the information system. During the integration, the developed solutions are in many cases functionally overlapped. Therefore several functions are related to one specific organization type and one function may belong to several organization types. Similarly, several datasets are related to one specific function and one dataset may belong to several functions. This more:more (N:M) type interconnections between the components / layers have been disaggregated to $1: \mathrm{N}$ connections for the proper data management.

When users and travellers use a certain function they are in connection with a content provider through the data and the functions via a personal device. In the most cases the architecture of the information system is irrelevant for them because the users perceive only the information service itself.

The modelling and the analysis can be performed by several aspects, with different resolutions (break-ups) either in aggregated approach or with considerations to the elements.

\section{CATEGORIZATION OF THE MODELS - MODELling METHODS}

Coherences between and inside the component type groups have been revealed and described in order to model and analyse the transportation information systems. Taking the applying purposes into consideration, model types according to several criteria have been elaborated. Coherences are illustrated in Figure 2.

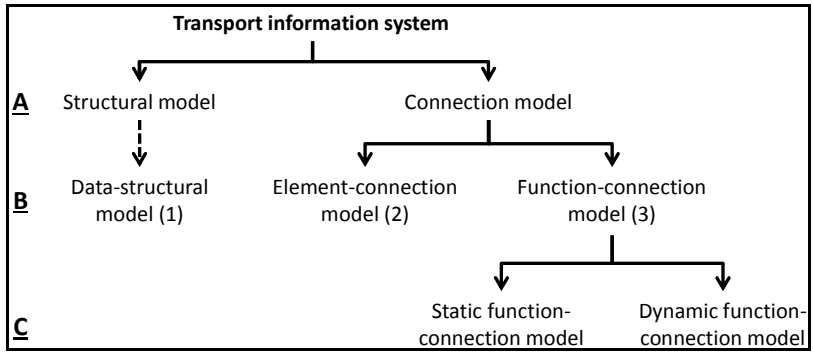

Fig. 2. Categorization of model types

For the taxonomy system theory approach was used, where the classification aspects were the following (A-C):

A Are the connections considered?

B What kind of component types are considered?

$\underline{\mathbf{C}}$ Are the temporary properties of the connections are considered? 


\section{A. Structure - Connection}

The structural models describe the hierarchical frame of the components. Connection models illustrate the relationships between the components (information managing elements and functions).

\section{B. Build-up - Operation}

The element-connection model describes the build-up of the system. The operation is illustrated by the functionconnection model. Relationships are realized by the flowing datasets. Accordingly, the relationships and datasets have been assigned to each other and the detailed properties of the relationships have been determined (e.g. direction, volume of data-flow, communication technology, etc.).

\section{Temporal properties of the operation}

In the case of function-connection models both functions and relationships have temporal properties. These properties have been disregarded in the static function-connection model. In the dynamic function-connection model functions and relationships have been categorized by the operation cycle time and in this way the static function-connection model has been disaggregated into layers. Each layer illustrates the functions and relationships working only in the given time cycle. Frequency and duration of transmissions belong to the temporal properties of the relationships.

The information managed by the organizations was identified, analysed and set into a uniform system, then the relationships and connections between the components were revealed and analysed. According to the types of components the following models are discussed in details:

1. The data-structural model is the frame of the data mapping of the transportation base-system.

2. The element-connection model describes the information managing elements and the relationships between them, also providing also the flowing datasets. Elements can be either human (organizations) or machine (subsystems) elements, but in this research machine elements were disregarded.

3. The function-connection model describes the information managing functions and the relationships between them, also providing also the flowing datasets.

Coherences of the $1^{\text {st }}$ model were used in the $2^{\text {nd }}$ and $3^{\text {rd }}$ models.

\section{STRUCTURAL MODEL OF ROAD TRANSPORTATION}

During the elaboration of the data structural model an approach with sequence of organization type, function, dataset has been applied. Step by step the investigation was broadened horizontally (model wideness) and vertically (model breakdowns) too. The broadening directions are discretely separated from each other. Figure 3. summarizes the modelling steps and its logic.

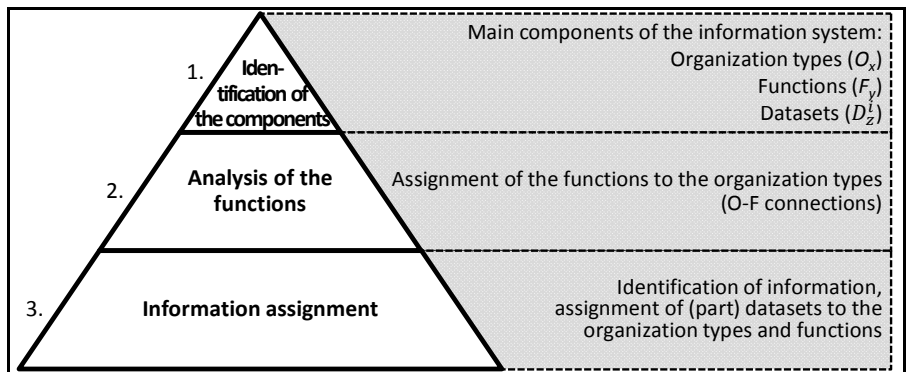

Fig. 3. Steps of the modelling of the information structure

The data structural model is the structure of the managed information according to the components. The model summarizes what kind of datasets are required for the operation of a certain function in a given organization type. The representation of the model is a matrix. The managed information sets are indicated in the cells (Figure 4.). The general model was applied for the road transportation. In the following tables the inherent organizations, functions and datasets are illustrated.

\section{Analysis method}

The matrix used for this analysis shows what kinds of datasets (column-header) are necessary for a function of an information managing element (two level row-headers). In simpler cases the "X" symbols indicate the coherences in the matrix; in case of more detailed analysis datasets can be disaggregated into further parts.

\section{Organization types $\left(O_{x}\right)$}

Road transport organizations were grouped based on their scope of duties (main tasks related to the base process of transportation) (Table I). The current Hungarian organizations were considered.

\section{Functions $\left(F_{y}\right)$}

The main functions related to the road transportation have been determined based on the duties of the organization types and ITS user services (Table II).

\section{Datasets $\left(D_{z}^{i}\right)$}

The managed data were sorted into 15 groups by the content and the temporal validity. Table III illustrates the results with examples. In this way, the data which are similar but map different content can be managed together.

Datasets $(z=1 \ldots 5)$ :

1. infrastructure based data,

2. road operational / service based data,

3. incident management data,

4. toll collection data,

5. user (passenger, vehicle and driver) data. 


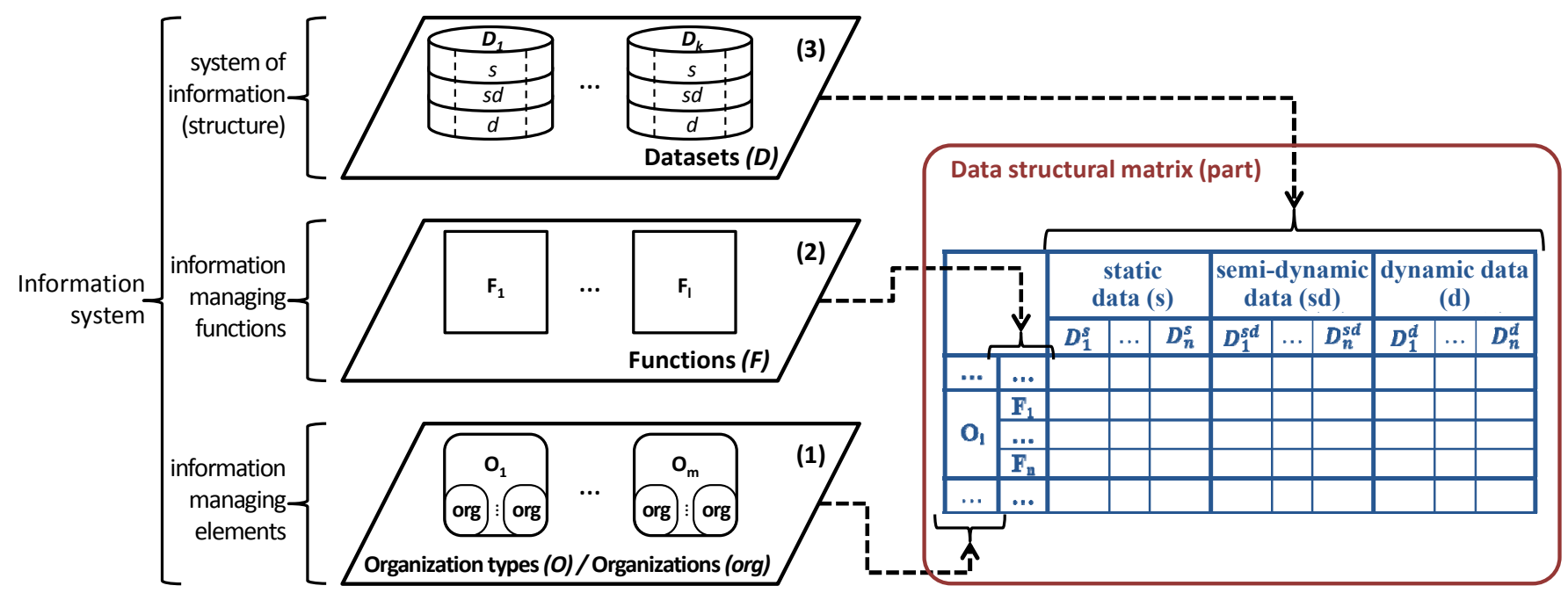

Fig. 4. Data structural model of the integrated system of information

TABLE I. ORGANIZATION TYPES

\begin{tabular}{|c|c|c|}
\hline Notation & Organization type & Description \\
\hline $\mathbf{O}_{1}$ & $\begin{array}{c}\text { Organizations responsible } \\
\text { for the management of } \\
\text { moving traffic }\end{array}$ & $\begin{array}{l}\text { Road operators (responsible for state } \\
\text { and municipality roads) and toll } \\
\text { companies. Toll collection and } \\
\text { enforcement often cannot be separated } \\
\text { from the traditional road operation, thus } \\
\text { the functions of toll collection also } \\
\text { belong to these organizations. } \\
\end{array}$ \\
\hline $\mathbf{O}_{2}$ & $\begin{array}{c}\text { Organizations responsible } \\
\text { for the management of } \\
\text { stationary traffic }\end{array}$ & Operators of parking facilities. \\
\hline $\mathbf{O}_{3}$ & $\begin{array}{l}\text { Fleet operator } \\
\text { organizations }\end{array}$ & $\begin{array}{l}\text { Market-based operators transporting } \\
\text { passengers or freights with own } \\
\text { information systems and a large amoun } \\
\text { of transportation (traffic) data. They can } \\
\text { contribute to the more efficient traffic } \\
\text { management by sharing this data. } \\
\end{array}$ \\
\hline $\mathbf{O}_{4}$ & $\begin{array}{c}\text { Transport organizers and } \\
\text { public road transport } \\
\text { operators }\end{array}$ & $\begin{array}{l}\text { Organizations operating within the } \\
\text { framework of the public service } \\
\text { contract who are responsible for the } \\
\text { preparation, order, organization, } \\
\text { operation and control of public services }\end{array}$ \\
\hline $\mathbf{O}_{5}$ & \begin{tabular}{|c|} 
Emergency services and \\
road authorities \\
(mid-level professional \\
coordination, tactical and \\
operational work) \\
\end{tabular} & $\begin{array}{l}\text { Organizations responsible for incident } \\
\text { management, enforcement and review. }\end{array}$ \\
\hline $\mathbf{O}_{6}$ & $\begin{array}{c}\text { State regulatory bodies } \\
\text { (ministries, municipalities, } \\
\text { background institutions) } \\
\text { (top-level professional } \\
\text { management, strategic } \\
\text { work) }\end{array}$ & $\begin{array}{l}\text { State administrative bodies, who are } \\
\text { responsible for the elaboration of the } \\
\text { legal and technical regulations of the } \\
\text { transportation, and the accounting } \\
\text { process of public services. }\end{array}$ \\
\hline
\end{tabular}

TABLE II. FUNCTIONS

\begin{tabular}{|c|c|c|}
\hline Notation & $\begin{array}{l}\text { Name of the } \\
\text { function }\end{array}$ & Description \\
\hline $\mathbf{F}_{1}$ & $\begin{array}{l}\text { Traffic } \\
\text { reporting }\end{array}$ & $\begin{array}{c}\text { Information on current and expected traffic } \\
\text { situations, road conditions, incidents and future } \\
\text { events. }\end{array}$ \\
\hline $\mathbf{F}_{2}$ & $\begin{array}{l}\text { Management of } \\
\text { traffic related } \\
\text { process }\end{array}$ & $\begin{array}{l}\text { Traffic control (conventional road traffic } \\
\text { management - the operation of traffic lights suited } \\
\text { to the actual traffic load, signal priority, traffic } \\
\text { interventions, speed control, incident management, } \\
\text { etc.), operative vehicle control, monitoring, } \\
\text { demand management (operational level) }\end{array}$ \\
\hline $\mathbf{F}_{3}$ & $\begin{array}{l}\text { Support of } \\
\text { public } \\
\text { transportation }\end{array}$ & $\begin{array}{c}\text { Supporting the operation of public transport } \\
\text { organizations: } \\
\text { traffic management; scheduling, route and line } \\
\text { planning, operation management, etc. (tactical and } \\
\text { operational planning level) }\end{array}$ \\
\hline $\mathbf{F}_{4}$ & $\begin{array}{l}\text { Support of } \\
\text { freight } \\
\text { transportation } \\
\text { and non-public } \\
\text { passenger } \\
\text { transportation } \\
\end{array}$ & $\begin{array}{c}\text { Organization of the passenger and freight traffic, } \\
\text { operation management: recording of dispositions, } \\
\text { route planning, accounting, tracking of goods and } \\
\text { vehicles, etc. (tactical and operational planning } \\
\text { level, without traffic intervention) }\end{array}$ \\
\hline$F_{5}$ & $\begin{array}{l}\text { (Electronic) toll } \\
\text { collection }\end{array}$ & $\begin{array}{l}\text { Solutions that enable the cash free payment of } \\
\text { infrastructure and service use. }\end{array}$ \\
\hline$F_{6}$ & $\begin{array}{c}\text { Increase traffic } \\
\text { safety }\end{array}$ & $\begin{array}{c}\text { Prevention and management of incidents and } \\
\text { dangerous traffic situations, V2X communication, } \\
\text { etc. }\end{array}$ \\
\hline $\mathbf{F}_{7}$ & $\begin{array}{l}\text { Increase } \\
\text { driving } \\
\text { efficiency }\end{array}$ & $\begin{array}{l}\text { Support of the fuel and cost saving vehicle driving } \\
\text { (e.g. eco-driving). }\end{array}$ \\
\hline $\mathbf{F}_{8}$ & $\begin{array}{l}\text { Increase of } \\
\text { comfort }\end{array}$ & $\begin{array}{l}\text { Increasing the comfort of driving and travelling, } \\
\text { mitigation of the drivers' and travellers' stress } \\
\text { effect during the transportation. }\end{array}$ \\
\hline
\end{tabular}




\section{Differentiation by temporal validity - dynamism} $(i=s, s d, d)$ :

$$
\begin{array}{ll}
\mathrm{s} & \text { static, } \\
\mathrm{sd} & \text { semi-dynamic, } \\
\mathrm{d} & \text { dynamic (including real-time data). }
\end{array}
$$

During the identification of the datasets the following factors were considered:
- datasets were to be defined on an abstracted level for the general model,

- although several datasets are overlapping, distinct groups had to be generated,

- time validity had to be also described by the model,

- some attributes of the traffic processes were linked to the infrastructure, because their spatial and / or temporal features are always associated with the infrastructure elements.

TABLE III. DATASETS

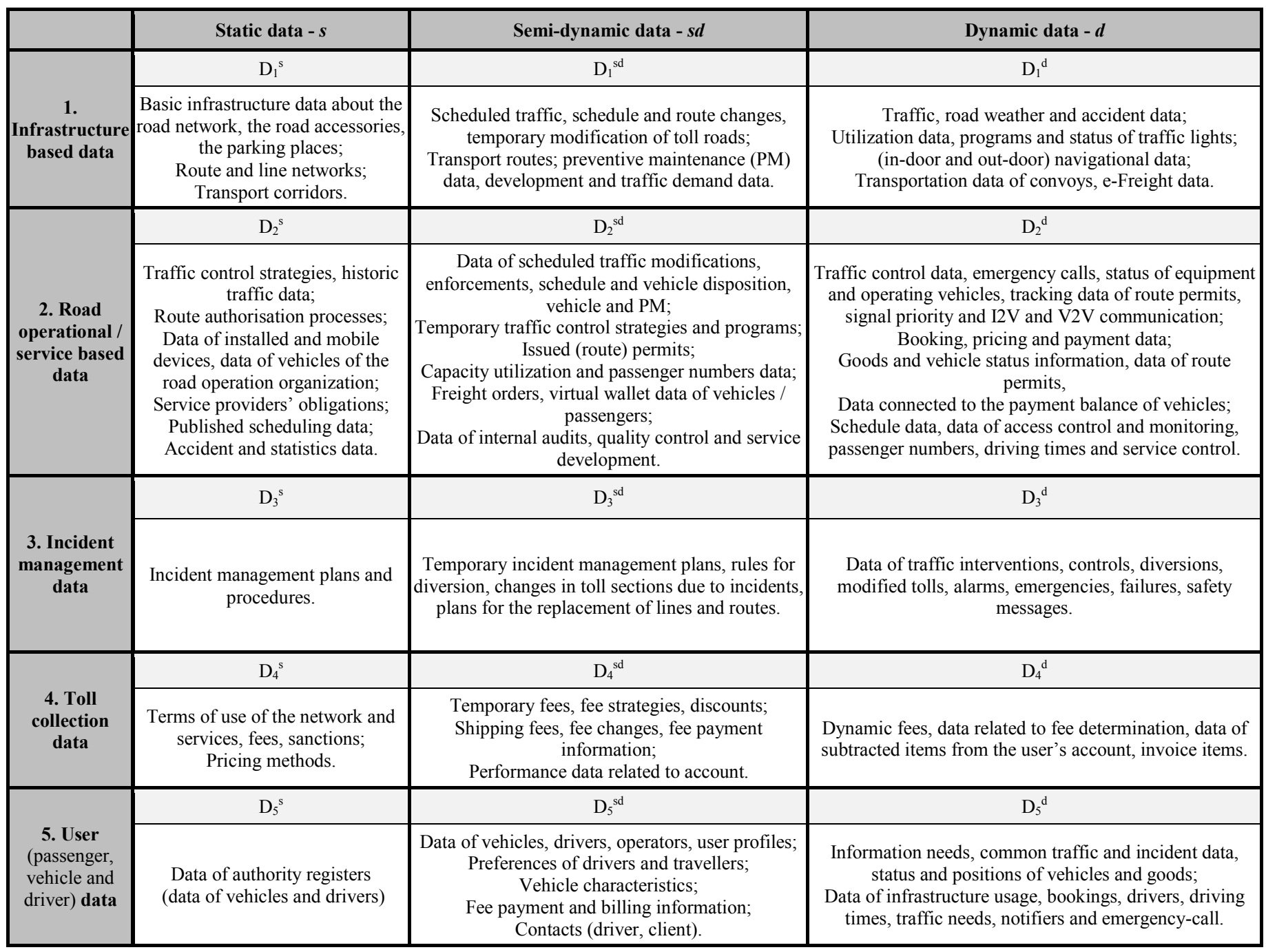

\section{CONNECTION MODEL OF ROAD TRANSPORTATION}

The connection model summarizes the connections and relationships between the organization types and the functions performed by them. The connections were established by the identification of the information flows between the components. The representation of the connection model is the information connection matrix. An elementary piece of information can be used by one or more information managing elements (depending on the content of the information). 
The flow of information or the accessibility to the information are realized through the connections. It depends on the system architecture and on push/pull type of transmission. The flow of information - within the transportation system, between the users and components- is realized by the use of machine subsystems and components. A single user may also have direct connections with an information managing element (e.g. in case of parking place booking).

\section{A. Element connection model}

Connections were revealed gradually and step-by-step. The sequence of organization type, function, dataset has been followed. Investigations were conducted between the same components; on the same resolution levels. Organization types that are operationally interconnected were identified. The results illustrated in Figure 5. In the matrix an " $\mathrm{X}$ " symbol indicates those pairs of organization types between which information transmission exists.

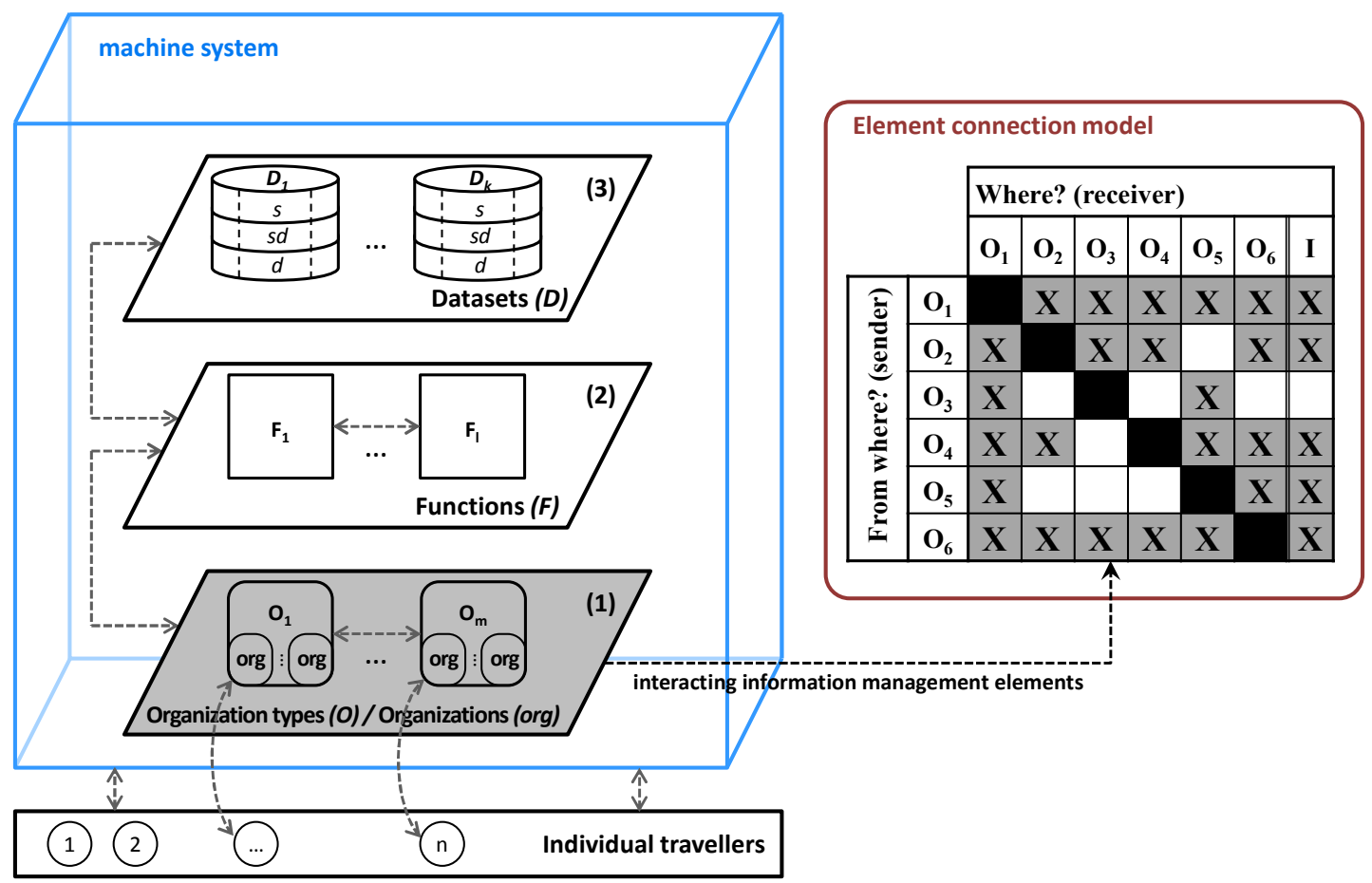

Fig. 5. Element connection model of the integrated system of information for road transport

During the elaboration of the model, only the information flow between the organization types was taken into consideration. The analysis of the information flows inside the organizations was disregarded.

Information is used by the individual travellers too, which is indicated by notation "I". Individual travellers appear in the model only as information users because they do not fulfil data management in organizational level.

\section{B. Function connection model}

For the analysis of the connections/relationships between the functions, the flows of information between the components were identified on the level of the functions. The matrix in Figure 6. illustrates the results. In the matrix an " $X$ " symbol indicates those function pairs between which information transmission exists.

\section{Analysis method}

The cells of the matrix can be divided into sub-cells by the use of the data-structural model. In this way, three dimensional coherences can be summarized in tables according to the three component types. The " $\mathrm{X}$ " symbols indicate the coherences in the (sub)cells of the matrix.

During a deeper analysis beside the determination of the existence of a connection further characteristics of the information flow and relationships can be identified (e.g. directions, transmitted (part) datasets, quantity of transmitted data, transmission frequency, transmission technology, etc.).

\section{THE "THREE-DIMENSIONAL" ANALYSIS}

The three component types can be illustrated by cuboids in the three-dimensional space. A cuboid - which can be identified by its coordinates on the axes - shows which dataset is managed by a certain function of an information management element. Its general method is illustrated in Figure 7. 


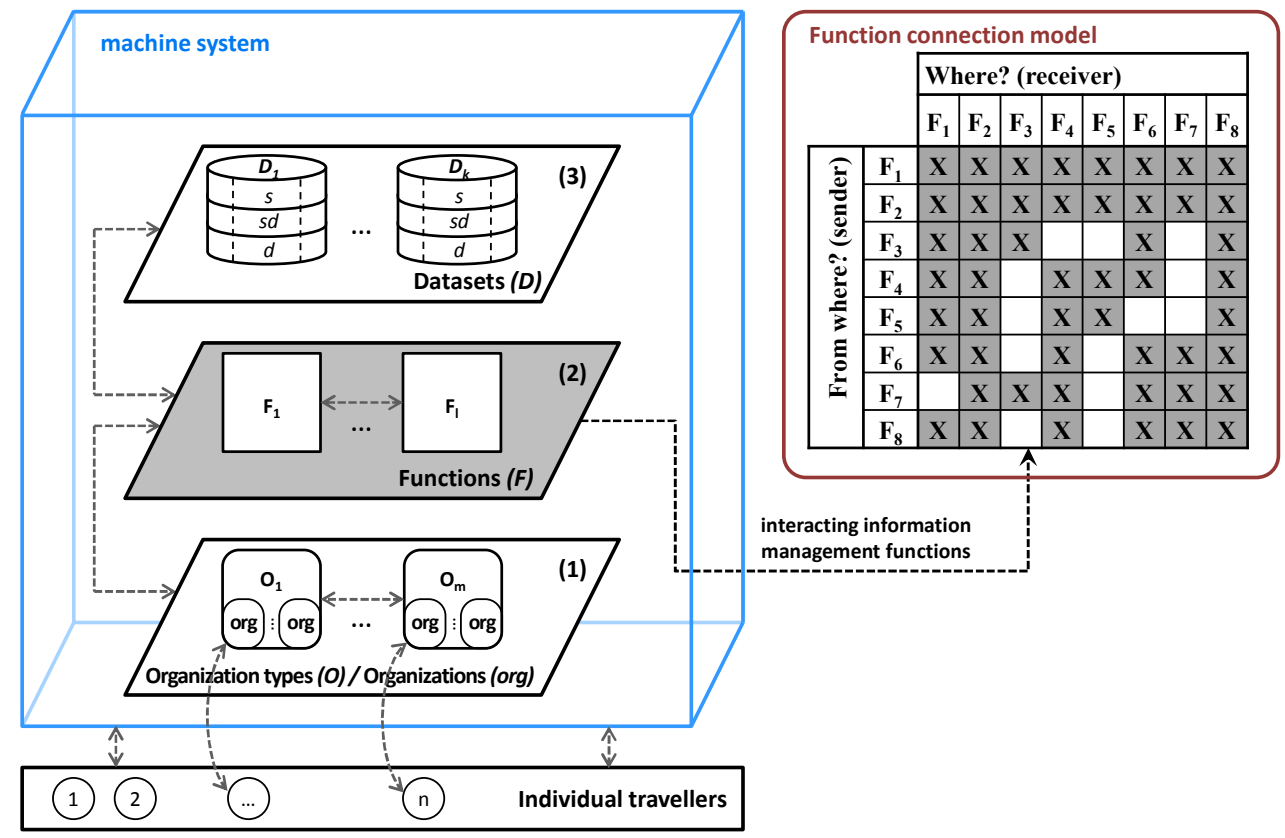

Fig. 6. Function connection model of the integrated system of information for road transport

The analysis can be performed by the creation of slices or projections along the axes. During slicing the entire cuboid is cut up at a chosen component. In this way, it is possible to examine the remaining components in relation to this specific component. During projection making it is possible to create two-dimensional summary figures (charts - projections). Leaving one dimension can be interpreted as sorting the components into one set by the given aspect. Projection making is an aggregation operation.

Due to the some datasets cohere with some functions not all cuboid exists. Where the datasets and functions do not give an explainable unity, the cuboid is missing. With the increasing of integration the number of missing cuboid can be decreased.

\section{FIELDS OF APPLICATION AND FURTHER RESEARCH DIRECTIONS}

The most important fields of application of the presented modelling and analysis methods are the following:

- comprehensive examination of the operation of organizations (base-process and information managing procedures), situation analysis, analysis of information demands, exploration of missing or inappropriate relationships,

- decision-making, preparation of organizational modifications,

- determination of the structure and operational properties of the machine system, capacity planning of elements,

- transportation research,

- logical preparation of the integration of transportation in terms of information.
The applicability of the model as a use case was proved by the analysis of the road operational activities at two national road operator company before their functional reorganization. Road operator tasks of the State Motorway Management Co were integrated into the Hungarian Public Road Nonprofit Private Limited Company [12].

\section{Further research directions:}

Enhancement of resolution: In the initial phase of the research the enhancement of the resolution of the component types was disregarded (macro models). In the further phases 'digging deeper' (micro models), the single information managing elements, the procedures and the data elements were attained in the end. Modelling and analysis with this high resolution can be performed just in a well-defined, smaller subsystem within the entire transportation information system. Figure 8. illustrates the method of breakdown of the components for elements situated on 'lower levels'.

Forming different component combinations then revealing and illustrating information connections/relationships in the connection matrix according to the combinations. For example, the matrix, which is formed with the consideration of both the organization type and the function, shows the following: which function of a certain organization type uses a dataset or its part originating from a certain function of a given organization type.

Adaptation of the analysis-modelling method for other modes of transportation. Thus the characteristics of other transportation modes can be revealed and compared. The extension of the model to other transportation modes facilitates the execution of the comprehensive integration of transport information systems. 


\section{VIII.CONCLUSION}

The main contribution to knowledge is the identification of model and analysis types, their elaboration and application in order to facilitate the integration of the information system of road transportation.

The following models have been created:

- model of the transportation information system,

- structural model of road transportation

- connection models (element and function connection models) of road transportation

The results have been also illustrated in matrices.

The introduced methods are appropriate for comprehensive preparation of the integration of transportation information systems on logical level. The subsequent steps on physical level can be derived from these analysis results in order to implement the required information technology components and to execute the needed modifications in the organizational structure.

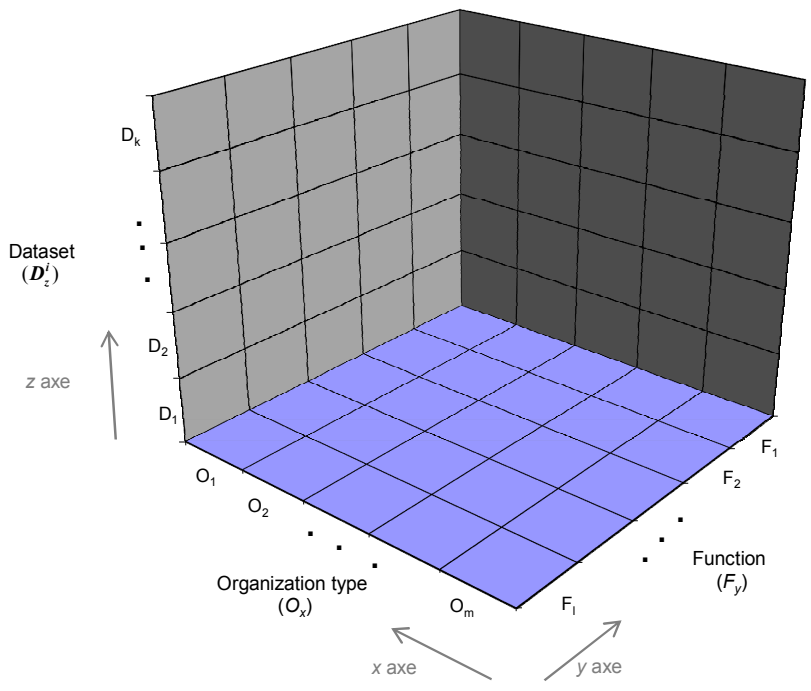

Fig. 7. The "three-dimensional" analysis of the information system

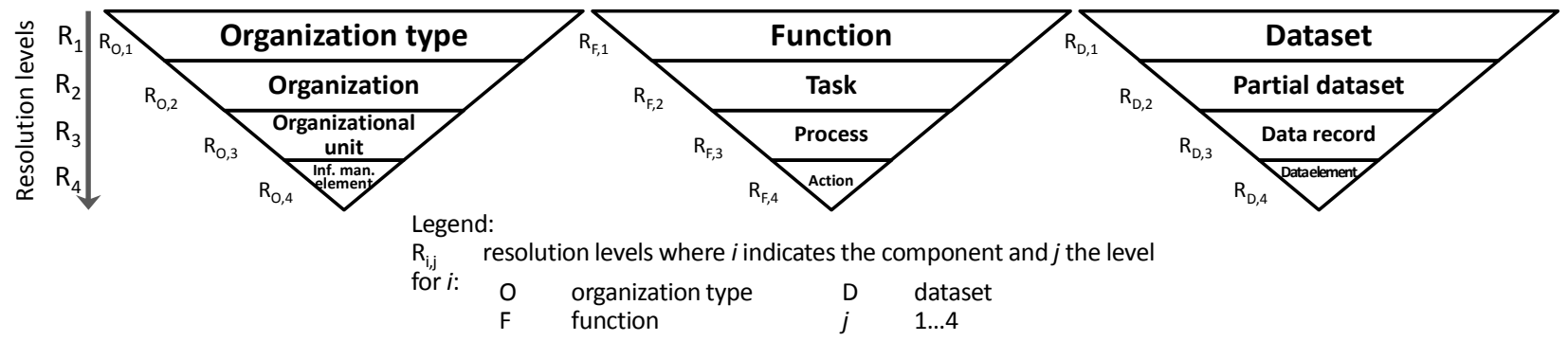

Fig. 8. The enhancement of the resolution in the analysis-modelling method

The most important lesson learnt was that realization of the efficient (quasi optimal) operation of organizations and individual users require the enhancement of the resolution attaining to the elementary components. Seeing this, we steadily continue the research.

\section{REFERENCES}

[1] ALlEKOTTE, D., GANSER, M., DINTER, M., WILlEMS, F.: Neue Lösungen für das strategische Verkehrsmanagement in der IGLZ Frankfurt am Main. Vortrag bei den verkehrswissenschaftlichen Tagen. Dresden 2003.*

[2] BOLTZE, M., WOLFERMANN, A., SCHÄFER, P.: Leitfaden Verkehrstelematik - Hinweise zur Planung und Nutzung in Kommunen und Kreisen. Leitfaden für die Planung und Nutzung der Telematik für kommunale Planungsträger zur Verbesserung der Verkehrsbedingungen in Städten, Gemeinden und Landkreisen. Technische Universität Darmstadt 2005 (pp. 9-40).*

[3] CSISZÁR, Cs.: Model of Integrated Intelligent Passenger Information Systems. Periodica Polytechnica. Transportation Engineering. Vol.31. No. 1-2. pp. 17-44. Budapest, 2003. DOI: 10.3311/pp.tr.2003-1-2.02

[4] HASBERG, P.: Straßenverkehrsmanagement in Großstädten. Rahmenbedingungen und das Projekt stadtinfoköln. 18. Verkehrswissenschaftliche Tage, Dresden 17.-18.09.2001*
[5] SANDROCK, M., RIEGELHUTH, G.: Verkehrsmanagementzentralen in Kommunen: Eine vergleichende Darstellung. Springer Vieweg; 2014 edition. (pp. 25-67.)*

[6] FENG, J., ZHU, Y., MUKAI, N., WATANABE, T.: Integrated management of multi-level road network and transportation networks. Lect. Notes Comput. Sci., 3683 (2005), pp. 677-683

[7] NASSER, K., ABDULLAH, A.H.: A Survey on Intelligent Transportation System. Middle-East J. Sci. Res. (2013), pp. 629-642

[8] MEIER, R., HARRINGTON, A., CAHILL, V.: A Framework for Integrating Existing and Novel Intelligent Transportation Systems. Proceedings of 2005 IEEE Intelligent Transportation Systems Conference, Vienna, Austria (Sep. 2005), pp. 154-159

[9] MUSSA, R.N., UPCHURCH, J.E., 2002. Simulator evaluation of incident detection by transponder-equipped vehicles. Transportation 29 (3), 287-305

[10] NOZICK, L., LIST, G.F., TURNQUIST, M.A., Wu, T.-L., 1998. Potential Effects of Advanced Technologies at Commercial Border Crossings. Transportation Research Record 1613, 88-95

[11] CSISZÁR, Cs., WESTSIK Gy.: Modelling of Computer Integrated Transportation. Periodica Polytechnica: Transportation Engineering Vol.27. No. 1-2. pp. 43-59. Budapest, 1999. DOI: 10.3311/pp.tr.1999-12.04

[12] SÁNDOR, Zs.: Modelling of the integrated system of information of road transportation, influencing the operational characteristics. $\mathrm{PhD}$ Dissertation (2015) Budapest University of Technology and Economics, Department of Transport Technology and Economics 